\title{
USE OF STANFORD2010 DATA FOR DETERMINATION OF EFFECT OF HARVESTER OPERATOR PERIODIC TRAINING ON PRODUCTIVITY AND FUEL ECONOMY
}

\author{
Aigars Strubergs ${ }^{1}$, Andis Lazdins ${ }^{2}$, Linards Sisenis ${ }^{1}$ \\ ${ }^{1}$ Latvia University of Life Sciences and Technologies, Latvia; \\ ${ }^{2}$ Latvian State Forest Research Institute "Silava", Latvia \\ aigars.strubergs@hotmail.com, andis.lazdins@silava.lv, linards.sisenis@1lu.lv
}

\begin{abstract}
The aim of the study is to clarify the effectiveness of operator qualification improvement courses through the analysis of harvester production data acquired according to the StanForD2010 standard. The study demonstrated that regular training of operators is used by AS "Latvian State Forests" (LSF) logging service providers; in turn, companies providing harvesting services in private forests pay much less attention to the periodic training of operators. The study uses automatically harvester production data acquired according to StanForD 2010 standard by LSF service providers. The study found that the most of the companies do not use the automatically acquired data of the harvester information system and their in-depth analysis capabilities through the grouping and analysis of each work cycle operation for evaluation of operators' productivity and for identification of operations where a particular operator should improve his skills. Second, the analysis of automatically acquired data enabled accurate detection of operations that significantly affected the changes in harvester fuel consumption before and after the qualification improvement courses. The study analyses data from two operators over a two months period prior to training and within a period of two months after training. The study approved that the harvester production files can be used for detailed evaluation of the training impact and demonstrated that after training both operators decreased the time consumed for stem gripping and processing on average by $5 \%$ and $16 \%$, specifically demonstrating those operations where productivity increased. The harvester production data also can be used to demonstrate the impact of fuel consumption, in this case training led to decrease fuel consumption per produced unit by $8 \%$ and $4 \%$. TimberOffice software was used for data grouping, while Microsoft Excel was used for data analysis.
\end{abstract}

Keywords: CTL harvester, big data, productivity, StanForD2010.

\section{Introduction}

In modern logging, with the introduction of increasingly modern and more powerful machines, effective work is not conceivable without highly qualified operators capable to utilize full spectrum of the opportunities offered by the machines. Consequently, there is an increasing need to improve periodically the qualifications of operators. [1]. Similarly, the analysis of operator work and operator training is essential for determination of possible reasons of a decline in the productivity or quality. Data needed for the analysis of operator productivity can be obtained in several ways. First, manual time studies using field computers and recording each operator's activity on site can be done [2]. Second, the options offered by StanForD 2010 production records, where operator's actions are automatically logged by the harvester management system, can be used [3-5]. Research has shown that the data obtained with the field computer by manual recording of operator's actions, are more accurate, however, such activities require additional human resources. In this case, the researcher should be on site, next to the harvester operator, watching and recording his activities [6]. In turn, using the data automatically acquired by the harvester IT system, their reliability is sufficient to use them in the productivity data analysis [2]. In Latvian logging companies operator productivity and fuel consumption are usually determined by the total production time per unit and the average amount of fuel consumed per time or per production unit. If these indicators are unsatisfactory, a decision is made on the operator's training. This approach does not give an idea about which operations the operator needs to improve in his craftsmanship. In such cases, a data analysis is required prior to operator training to identify the weak spots in the production process. So, consequently, during the training there would be a clear picture of which operations need more attention and improvements. In turn, it is possible to assess the effectiveness of the training and whether the set goal has been achieved through production data analysis after completion of training. Without the determination of specific operations requiring more attention, it would be difficult to evaluate if the training goal has been achieved, because the total productivity is likely to slightly increase, but the operator could continue to make errors in the execution of certain operations during the logging process. Ideally, training could be organized on simulators, thus providing all trainees with the same conditions, making it easier to compare the performance of operators with each other [7]. 


\section{Materials and methods}

The study uses automatically acquired data from a harvester John Deere 1270 E equipped with a harvester head $\mathrm{H} 480$. The harvester uses a measurement system for Timbermatic H 1.28.16 and supports StanForD 2010. The harvester works in thininng in Joint stock company "Latvia's state forests" (LVM) managed forests. Data have been obtained from two operators' work records acquired two months before and two months after training, during the period from November 2020 to February 2021. In total, data were obtained from nine stands. During this period, 21988 trees with a total volume of $2105 \mathrm{~m}^{3}$ were processed. Average volume of processed stem is $0.15 \mathrm{~m}^{3}$. The work experience of both operators is half of a year after harvesting machine operator qualification in technical school. Operator training was carried out for one day in real work conditions in felling. The training was carried out by an experienced instructor with extensive practical experience. The study uses data derived from the harvester IT system. Data analysis uses files hpr, .mom and Harald DB. The TimberOffice 5.12 program is used to open these files for information acquisition. The following acquired data are transferred for further processing in Microsoft Excel. In the spreadsheet application data are entered for each operator separately, respectively, operator 1 and operator 2. Five felling areas before training and four felling areas after training were selected for each operator in the TimberOffice program. Operator's work in each felling site was distributed according to a time scale. Productivity and average tree volume was determined from the production report, while the time consumption of each operation in each felling site was determined using the TimberMatic Analytics tool. Firstly, in each felling site, stems were divided into groups by stem mean volume, from which six groups were obtained with the following volume intervals: $0.00-0.15 \mathrm{~m}^{3}, 0.15-0.30 \mathrm{~m}^{3}, 0.30-0.50 \mathrm{~m}^{3}, 0.50-0.80 \mathrm{~m}^{3}, 0.80-1.20 \mathrm{~m}^{3}$ and $1.20-1.70 \mathrm{~m}^{3}$. In each stem volume group, the time spent to execute operations starting from gripping of the stem and the time that the operator needed for stem processing, including cross-cut into individual assortments is completed. These figures were then summed up and the time consumed for the processing of a stem before and after training was compared. Secondly, the time spent by the operators for execution of specific operations was determined. In TimberOffice the time consumed by the operator for each operation in the production process is acquired in thinnings. Stem selection and cutting was considered separately. Selected group of operations includes driving, reaching tree, gripping, tree stripping and the rest of the work time. The other group is stem processing. Stem processing includes time consumed only for boom movements, time where boom moves simultaneously with stem processing, bucking and the rest of the time. The other time of each group includes activities that are not recorded separately by the harvester information system. Here, actions such as tree selection and wood damage determination can be listed. Thirdly, the average fuel consumption of $\mathrm{L} \mathrm{h}^{-1}$ was compared, as consumed in the performance of each operation before and after training. All necessary data were transferred from TimberOffice to Microsoft Excel, where further data processing was carried out. Using Fisher's test, the significance of difference of the results obtained was determined.

\section{Results and discussion}

When performing data analysis for both operators, it is found that the time consumed for stem selection, gripping and processing is not significantly different before and after training. Also, the analysis of variance did not show any significant difference between the time spent for a stem processing before and after training $p=0.057>0.05$ (Fig. 1).

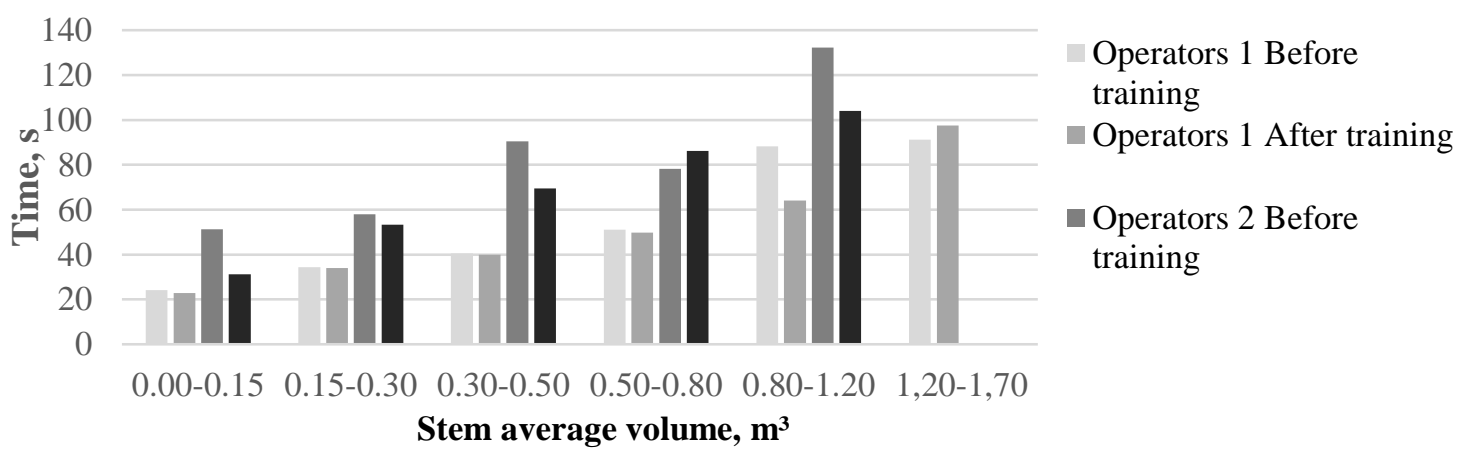

Fig. 1. Stem processing time before and after training in individual stem volume groups 
The figure shows that the biggest differences after training for operator 1 are in stem volume group of $0.80-1.20 \mathrm{~m}^{3}$, while for operator 2 - in stem volume group $0.00-0.15 \mathrm{~m}^{3}$. Although the total time difference in stem gripping and processing is not statistically significant, calculation of percentage of the time reduction for stem processing in individual volume groups, the difference is significant (Table 1).

Table 1

Total stem processing time in individual volume groups (s)

\begin{tabular}{|c|c|c|c|c|c|c|}
\hline \multirow{2}{*}{ Stem volume $\left(\mathbf{m}^{\mathbf{3}}\right)$} & \multicolumn{3}{|c|}{ Operator 1 } & \multicolumn{3}{c|}{ Operator 2 } \\
\cline { 2 - 7 } & $\begin{array}{c}\text { Before } \\
\text { training }\end{array}$ & $\begin{array}{c}\text { After } \\
\text { training }\end{array}$ & Time saving\% & $\begin{array}{c}\text { Before } \\
\text { training }\end{array}$ & $\begin{array}{c}\text { After } \\
\text { training }\end{array}$ & Time saving\% \\
\hline $0.00-0.15$ & 24.1 & 22.8 & 5 & 51.3 & 31.3 & 39 \\
\hline $0.15-0.30$ & 34.3 & 34.1 & 1 & 57.9 & 53.3 & 8 \\
\hline $0.30-0.50$ & 40.4 & 39.9 & 1 & 90.5 & 69.5 & 23 \\
\hline $0.50-0.80$ & 51.1 & 49.7 & 3 & 78.2 & 86.1 & -10 \\
\hline $0.80-1.20$ & 88.3 & 64.0 & 27 & 132.3 & 104.0 & 21 \\
\hline $1,20-1,70$ & 91.3 & 97.5 & -7 & - & - & - \\
\hline
\end{tabular}

After one-day training, the average time for stem processing for operator 1 decreased by $5 \%$ in all volume groups, while for operator 2 the average stem processing time in all volume groups decreased by $16 \%$. The time consumption has been considered separately for different operation performances: stem gripping, removal, and further stem processing. Also, in these categories, statistically significant differences before and after training were not observed at $\mathrm{p}=0.31>0.05$; however, through training, time economy has been achieved in some operations (Fig. 2.).

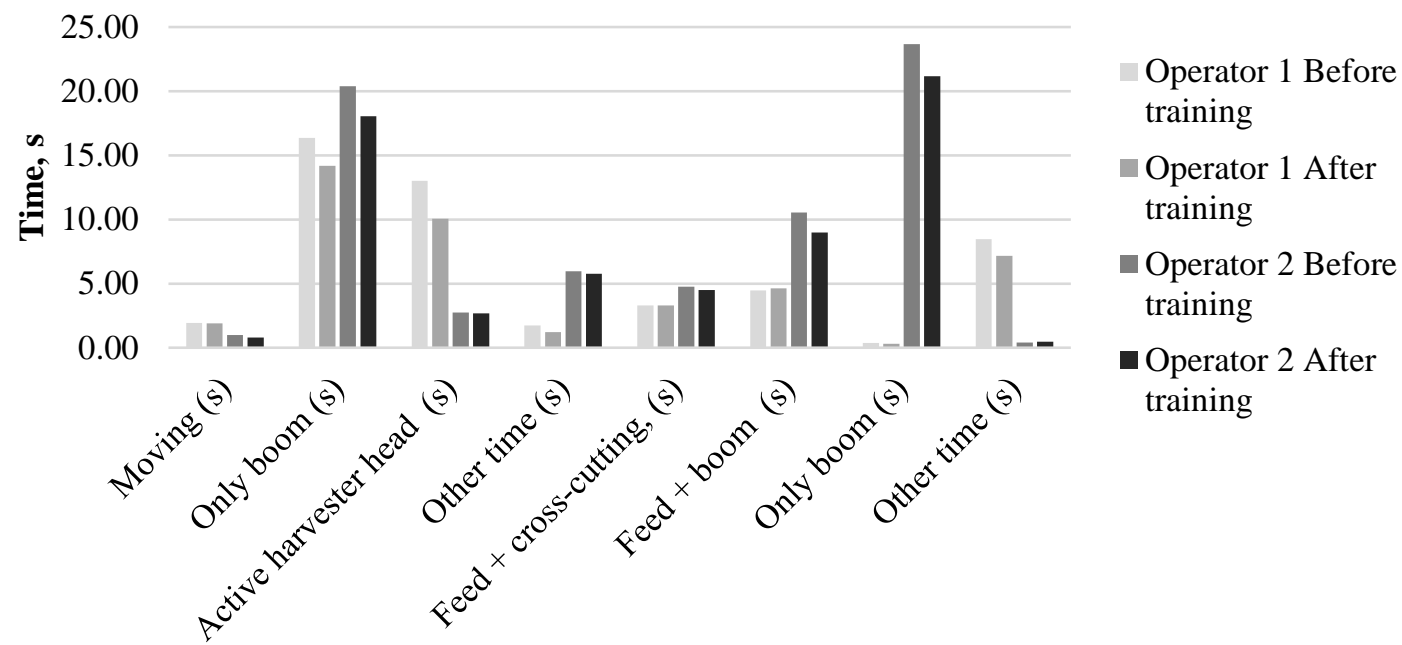

Operations

Fig. 2. Time consumption for individual operations before and after training

Although changes in the consumed time have not been identified after training in the performance by the individual operations, in relative terms the productivity improvements of both operators are noticeable (Table 2).

In the individual work operations, the time consumed by operator 1 after training decreased on average by $12 \%$, while by operator $2-$ by $7 \%$. It is obvious according to the obtained data that the largest time decrease for operator 1 is observed for the operation "other time" during the period when the tree is selected and gripped, but for operator 2 the biggest time reduction is observed in the operation "driving", also during the period when the tree is gripped. For both operators the situations when the time spent in some positions is increased have been observed, furthermore, the increase of time consumption was observed for both operators during the stem processing. 
Changes in the time consumed for execution of individual operations

\begin{tabular}{|c|c|c|c|c|c|c|c|}
\hline \multirow{3}{*}{ Period } & \multirow{2}{*}{ Operations } & \multicolumn{3}{|c|}{ Operator 1 } & \multicolumn{3}{c|}{ Operator 2 } \\
\cline { 2 - 8 } & $\begin{array}{c}\text { before } \\
\text { training }\end{array}$ & $\begin{array}{c}\text { after } \\
\text { training }\end{array}$ & $\begin{array}{c}\text { time } \\
\text { saving\% }\end{array}$ & $\begin{array}{c}\text { before } \\
\text { training }\end{array}$ & $\begin{array}{c}\text { after } \\
\text { training }\end{array}$ & $\begin{array}{c}\text { time } \\
\text { saving\% }\end{array}$ \\
\hline \multirow{4}{*}{ Stem grip } & Driving & 1.91 & 1.89 & 1 & 0.99 & 0.79 & 20 \\
\cline { 2 - 8 } & Boom moving & 16.37 & 14.18 & 13 & 20.39 & 18.06 & 11 \\
\cline { 2 - 8 } & $\begin{array}{c}\text { Active harvester } \\
\text { head }\end{array}$ & 13.00 & 10.06 & 23 & 2.75 & 2.67 & 3 \\
\cline { 2 - 8 } & Other time & 1.72 & 1.23 & 29 & 5.97 & 5.78 & 3 \\
\hline \multirow{4}{*}{$\begin{array}{c}\text { Stem } \\
\text { processing }\end{array}$} & $\begin{array}{c}\text { Feeding and } \\
\text { bucking }\end{array}$ & 3.31 & 3.28 & 1 & 4.74 & 4.50 & 5 \\
\cline { 2 - 8 } & $\begin{array}{c}\text { Feeding and boom } \\
\text { movement }\end{array}$ & 4.46 & 4.62 & -4 & 10.55 & 8.98 & 15 \\
\cline { 2 - 8 } & Boom movement & 0.36 & 0.30 & 18 & 23.65 & 21.17 & 11 \\
\cline { 2 - 8 } & Other time & 8.46 & 7.17 & 15 & 0.41 & 0.46 & -11 \\
\hline
\end{tabular}

Individual stem volume groups were not analyzed during evaluation of fuel consumption, which is split into individual operations before and after the training. According to the obtained results, training does not have statistically significant effects on the fuel consumption at $p=0.29>0.05$. However, when comparing the fuel consumption rates before and after training, the reduction of fuel consumption was noticeable. Possible reason for insufficient significance is diversity of the volume of processed stems increasing diversity of fuel consumption per operation. The results are presented in Table 3.

Table 3

Fuel consumption changes before and after training

\begin{tabular}{|c|c|c|c|c|c|c|}
\hline \multirow{2}{*}{ Operation } & \multicolumn{3}{|c|}{ Operator 1 } & \multicolumn{3}{|c|}{ Operator 2 } \\
\cline { 2 - 7 } & $\begin{array}{c}\text { before, } \\
\mathrm{L} \cdot \mathrm{h}^{-1}\end{array}$ & $\begin{array}{c}\text { after, } \\
\mathrm{L} \cdot \mathrm{h}^{-1}\end{array}$ & $\begin{array}{c}\text { Reduction of } \\
\text { fuel } \\
\text { consumption\% }\end{array}$ & $\begin{array}{c}\text { before. } \\
\mathrm{L} \cdot \mathrm{h}^{-1}\end{array}$ & $\begin{array}{c}\text { after, } \\
\mathrm{L} \cdot \mathrm{h}^{-1}\end{array}$ & $\begin{array}{c}\text { Reduction of } \\
\text { fuel } \\
\text { consumption\% }\end{array}$ \\
\hline Feeding & 22.96 & 20.53 & 11 & 21.29 & 19.84 & 7 \\
\hline Cutting & 23.16 & 21.18 & 9 & 22.76 & 21.73 & 5 \\
\hline Processing & 19.76 & 17.93 & 9 & 18.24 & 17.96 & 2 \\
\hline Only boom & 16.08 & 15.45 & 4 & 15.96 & 15.87 & 1 \\
\hline Driving & 16.76 & 15.88 & 5 & 16.08 & 15.14 & 6 \\
\hline
\end{tabular}

According to Table 3, the impact of training on the fuel consumption has been positive in all stem processing operations for both operators. The most significant fuel economy for both operators appears during the stem supply, by $11 \%$ and $7 \%$, accordingly. When comparing total fuel consumption before and after training, the fuel economy has been achieved by both operators, on average by $8 \%$ and $4 \%$, accordingly. The study results clearly demonstrate the advantages of the utilization of harvester production files in evaluation of the demand and the results of training of operators, including detailed evaluation of the impact on the performance and fuel consumption during different operations. Modern IT systems in harvesters is a powerful tool to monitor and improve performance of the operators.

There are also studies demonstrating the performance analysis of forest machine operators using the harvester simulator data [8; 9]. However, according to the authors of these studies in real life conditions, the productivity and the time spent for every operation is affected by multiple interfering factors, which cannot be predicted in simulations. One of the main factors is the volume of an extracted tree. Increase of the stem volume normally increases productivity [10], which is approved by this study, too. No decrease of productivity or different productivity values while processing trees of different dimensions were not found in the study - the improvements achieved were general and reflected in all dimension's classes. Further improvements, which can be implemented in monitoring of the harvesting process, is quality of thinning (e.g., basal area of remaining trees, total area of strip-roads, soil damages); however, these functions are not yet implemented in tools available for practitioners [11]. 


\section{Conclusions}

1. The production data records of the harvester acquired according to the StanForD2010 standard provide sufficient amount of information to evaluate the training effects on the time spent and fuel consumption for different stem processing operations.

2. One-day training has improved the productivity rates for operator 1 . The time consumed in stem gripping and processing for operator 1 and operator 2 has decreased on average, accordingly, by $5 \%$ and $16 \%$, the impact on particular operations can be identified.

3. The time consumed for the execution of individual logging operations has decreased on average by $12 \%$ and $7 \%$, accordingly for operator 1 and 2 . The harvester production data also demonstrated that the impact is general - have similar impact on processing of different dimension stems.

4. The study also demonstrated that modern harvester production data can be used to evaluate impact on the fuel consumption, in the study the fuel consumption decreased on average by $8 \%$ and $4 \%$ for operator 1 and 2, accordingly; however, the difference is not statistically significant, when evaluated as for single operations.

\section{References}

[1] Nurminen T., Korpunen H. \& Uusitalo J. Time consumption analysis of the mechanized cut-to-length harvesting system. Silva Fennica vol. 40(2), 2006, pp. 335-363.

[2] Brewer J., Talbot B., Belbo H. etc. A comparison of two methods of data collection for modelling productivity of harvesters: manual time study and follow-up study using on-board-computer stem records. Annals of Forest Research, vol. 61(1), 2018, pp. 109 - 124.

[3] Arlinger J., Möller J., Sorsa J.A. etc. Introduction to StanForD2010. Structural descriptions and implementation recommendations. Skogforsk. 74 p. [online] [20.02.2020]. Available at https://www.skogforsk.se/contentassets/1a68cdce4af1462ead048b7a5ef1cc06/stanford-2010introduction-150826.pdf

[4] Purfürst F. T., Erler J. (2011). The Human Influence on Productivity in Harvester Operations. International Journal of Forest Engineering, vol. 22(2), 2011, pp. 15-22.

[5] Eriksson M., Lindroos O. Productivity of harvesters and forwarders in CTL operations in northern Sweden based on large follow-up datasets. International Journal of Forest Engineering, vol. 25(3), 2014, pp. 179-200.

[6] Palander T., NuutinenY., Kariniemi A. etc. Automatic time study method for recording work phase times of timber harvesting. Forest Science, vol.59(4), 2013, pp. 472-483.

[7] Nuutinen Y., Väätäinen K., Heinonen J. etc. The accuracy of manually recorded time study data for harvester operation shown via simulator screen. Silva Fennica, vol. 42(1), 2008, pp. 63-72.

[8] Palander T., Ovaskainen H.,Tikkanen L. An Adaptive Work Study Method for Identifying the Human Factors that Influence the Performance of a Human-Machine System. Forest Science, vol. 58(4), 2012, pp. 377-389.

[9] Nuutinen Y., Väätäinen K., Heinonen J. etc. The accuracy of manually recorded time study data for harvester operation shown via simulator screen. Silva Fennica 42(1), 2008, pp. 63-72.

[10] Alam M., Walsh D., Strandgard M. etc. A log-by-log productivity analysis of two Valmet 475EX harvesters. International Journal of Forest Engineering, vol 25(1), 2014, pp 14-22.

[11] Malinen J., Taskinen J., Tolppa T. Productivity of Cut-to-Length Harvesting by Operators' Age and Experience. Croatian Journal of Forest Engineering vol. 39(1), 2018, pp. 14-22. 